\title{
Canine respiratory coronavirus employs caveolin-1-mediated pathway for internalization to HRT-18G cells
}

\author{
Artur Szczepanski 1,2, Katarzyna Owczarek ${ }^{1,2}$, Aleksandra Milewska ${ }^{1,2}$, Zbigniew Baster $^{3}$, Zenon Rajfur ${ }^{3}$, \\ Judy A. Mitchell ${ }^{4}$ and Krzysztof Pyrc ${ }^{1,2^{*}}$ (D)
}

\begin{abstract}
Canine respiratory coronavirus (CRCoV), identified in 2003, is a member of the Coronaviridae family. The virus is a betacoronavirus and a close relative of human coronavirus OC43 and bovine coronavirus. Here, we examined entry of CRCoV into human rectal tumor cells (HRT-18G cell line) by analyzing co-localization of single virus particles with cellular markers in the presence or absence of chemical inhibitors of pathways potentially involved in virus entry. We also targeted these pathways using siRNA. The results show that the virus hijacks caveolin-dependent endocytosis to enter cells via endocytic internalization.
\end{abstract}

\section{Introduction}

Coronaviruses are enveloped, single-stranded, positivesense RNA viruses belonging to the family Coronaviridae within the order Nidovirales [1]. Based on its properties, this family can be divided into four distinct genus: alpha, beta, delta, and gamma. Coronaviruses infect a wide variety of birds and mammals, including humans, livestock, and companion animals [1-3]. Human coronaviruses (HCoVs) are associated mainly with relatively mild upper and lower respiratory tract disease; however, emergence of severe acute respiratory syndrome coronavirus (SARS$\mathrm{CoV}$ ) in the winter of 2002-2003 in China, and more recently Middle East respiratory syndrome coronavirus (MERS-CoV) in the Middle East, demonstrates the potential threat posed by zoonotic coronaviruses [2-4].

Canine respiratory coronavirus $(\mathrm{CRCoV})$ was first identified in 2003 in samples obtained from the respiratory tracts of dogs with canine infectious respiratory disease (CIRD; also known as kennel cough) that were housed in animal shelters in the United Kingdom [5]. CIRD is a contagious disease with high morbidity but

\footnotetext{
*Correspondence: k.a.pyrc@uj.edu.pl

${ }^{2}$ Faculty of Biochemistry, Biophysics and Biotechnology, Jagiellonian University, Krakow, Poland

Full list of author information is available at the end of the article
}

low mortality; it usually occurs in densely housed dog populations (e.g., rehoming centers, veterinary hospitals). Characterized by a dry, hacking cough, the disease is generally mild and self-limiting. However, it can progress to a potentially fatal bronchopneumonia [6,7]. CIRD is considered a complex infection, with a multifactorial etiology in which a number of organisms (including Bordetella bronchiseptica, canine parainfluenza virus, canine adenovirus type 1 and 2, canine herpesvirus, Mycoplasma spp., canine pneumovirus, and influenza viruses) are involved $[6,8]$. It is believed that $\mathrm{CRCoV}$ plays a role in the early stages of CIRD by limiting ciliary clearance of the upper airways. Consequently, infection leads to reduced respiratory clearance and sensitization to secondary infections [5-7].

CRCoV is closely related to two other betacoronaviruses, bovine coronavirus $(\mathrm{BCoV})$ and $\mathrm{HCoV}-\mathrm{OC} 43$ (97.3\% nucleotide identity in the spike gene for $\mathrm{BCoV}$ and $96.9 \%$ for OC43 as reported by Erles et al. [5]), but is clearly distinct from Canine Enteric Coronavirus (CECoV, previously known as Canine Coronavirus) [5, 7]. $\mathrm{CRCoV}$ is a difficult pathogen to work with because the only confirmed susceptible cell line is a human rectal tumor cell line (HRT-18) and its derivative HRT-18G. No canine cell line supports replication of the virus. 
Furthermore, $\mathrm{CRCoV}$ does not produce a cytopathic effect in HRT-18 cells [8].

To initiate infection, enveloped viruses fuse with host cell membrane prior to delivering genetic material. This process may occur at the cell surface (e.g., human immunodeficiency virus, herpes simplex virus); otherwise prior internalization is required [2,9]. To enter the cell, viruses hijack a number of different endocytic pathways, including macropinocytosis and clathrin-mediated, caveolin-mediated, and clathrin- and caveolin-independent routes $[2,9,10]$. For example, SARS-CoV uses clathrindependent, lipid raft-mediated, and clathrin- and caveolae-independent entry pathways [2, 11-13]. In addition, feline infectious peritonitis virus (FIPV) uses clathrinand caveolin-independent endocytic routes [14], whereas HCoV-229E uses caveolae-dependent endocytosis [15]. Furthermore, some human respiratory coronaviruses may utilize protease activation to modulate the route of entry [16-18]. Generally, within each of these endocytic pathways, vesicles are formed through interaction of certain protein networks. Early vesicles provide a starting point for trafficking, which leads to endosome maturation and allows sorting of incoming cargo [19, 20]. Some internalized vesicles are recycled back to the cell surface, while others are converted, for example to lysosomes. Sorting of cargo is regulated by Rab GTPases, which serve as molecular hallmarks of different routes [19-21].

Here, we studied internalization of CRCoV into HRT$18 \mathrm{G}$ cells. The results clearly demonstrated that $\mathrm{CRCoV}$ entry into HRT-18G cells requires endocytic internalization prior to membrane fusion, a process that requires caveolin-1 and dynamin. Furthermore, fusion of the viral and cellular membranes occurs before the endosome progresses to the late phase.

\section{Materials and methods \\ Cells and viruses}

HRT-18G (ATCC CRL-11663) cells, derivative of HRT-18 (ATCC CCL-244, ileocecal colorectal adenocarcinoma) were maintained in Dulbecco's MEM (Life Technologies, Poland) supplemented with $3 \%$ heat-inactivated fetal bovine serum (Life Technologies), penicillin $(100 \mathrm{U} / \mathrm{mL}$ ), streptomycin $(100 \mu \mathrm{g} / \mathrm{mL})$, and ciprofloxacin $(5 \mu \mathrm{g} / \mathrm{mL})$. Cells were cultured at $37{ }^{\circ} \mathrm{C}$ under $5 \% \mathrm{CO}_{2}$. Virus stock of canine respiratory coronavirus strain 4182 was prepared by infecting HRT-18G cells monolayers and collecting supernatant 5 days post-infection (pi). Obtained stock was aliquoted and stored at $-80{ }^{\circ} \mathrm{C}$. The control from mock-infected cells was prepared in the same manner. Virus yield was estimated by titration on confluent HRT$18 \mathrm{G}$ cells according to the method of Reed and Muench [22]. As CPE is not visible, cells were infected at $37^{\circ} \mathrm{C}$ for 5 days, fixed and immunostained to detect virus-infected cells. For co-localization studies, stocks were concentrated using Amicon Ultra Centrifugal Filters (Merck, 10-kDa cutoff), aliquoted, and stored at $-80{ }^{\circ} \mathrm{C}$.

\section{Chemical inhibitors}

DMEM supplemented with $100 \mathrm{U} / \mathrm{mL}$ penicillin, $100 \mu \mathrm{g} /$ $\mathrm{mL}$ streptomycin and one of the following chemical inhibitors: 1-aminoadamantane $(100 \mu \mathrm{M}$, AMTD, Sigma-Aldrich, Poland), Pitstop (10 $\mu \mathrm{M}$, Abcam), chlorpromazine $(1.5 \mu \mathrm{M}$, Sigma-Aldrich), filipin III $(2 \mu \mathrm{g} / \mathrm{mL}$, Sigma-Aldrich), nystatin (50 $\mu \mathrm{g} / \mathrm{mL}$, Sigma-Aldrich), methyl- $\beta$-cyclodextrin (5 mM, M $\beta C D$, Sigma-Aldrich), 5-( $N$-ethyl- $N$-isopropyl)amiloride $(10 \mu \mathrm{M}$, EIPA, SigmaAldrich), 1,1'-Dithiobis-2-naphthalenol (20 $\mu \mathrm{M}$, IPA3, Sigma-Aldrich), wortmannin (5 $\mu \mathrm{M}$, Calbiochem), dynasore $(80 \mu \mathrm{M}$, Abcam), iminodyn $22(25 \mu \mathrm{M}$, Abcam), mitmab $(5 \mu \mathrm{M}, \mathrm{Abcam})$, ammonium chloride $(50 \mathrm{mM}$, $\mathrm{NH}_{4} \mathrm{Cl}$, Bioshop), bafilomycin A1 (10 nM, SigmaAldrich), cytochalasin D (10 $\mu \mathrm{M}$, Sigma-Aldrich), jasplakinolide $(1.5 \mu \mathrm{M}$, Calbiochem), nocodazole $(0.5 \mu \mathrm{M}$, Sigma-Aldrich), cell permeable Rho inhibitor $(1 \mu \mathrm{g} / \mathrm{mL}$, CT04 Cytoskeleton Inc.), $N^{6}$-[2-[[4-(Diethylamino)1-methylbutyl]amino]-6-methyl-4-pyrimidinyl]-2-methyl-4,6-quinolinediamine trihydrochloride $(100 \mu \mathrm{M}$ NSC23766), (R)-(+)-trans-4-(1-Aminoethyl)- $N$-(4-Pyridyl)cyclohexanecarboxamide dihydrochloride $(10 \mu \mathrm{M}$, Y27632 Sigma-Aldrich), Decanoyl-Arg-Val-Lys-Argchloromethyl ketone (5-100 $\mu \mathrm{M}$, Santa Cruz Biotechnology) were used to pretreat HRT-18G cells for $1 \mathrm{~h}$ at $37^{\circ} \mathrm{C}$.

\section{Inhibition of viral replication}

Cells pretreated with chemical inhibitors for $1 \mathrm{~h}$ at $37^{\circ} \mathrm{C}$ (full list at Additional file 1), were exposed to virus at a $50 \%$ tissue culture infectious dose $\left(\mathrm{TCID}_{50}\right)$ of 400 in the presence of inhibitors. Two hours pi cells were washed with PBS twice to remove unbound virus, and medium with fresh inhibitors was added to each well. Five days pi cells were harvested for further analysis. Cell viability was tested at day five pi using XTT based Cell Proliferation Kit (Biological Industries), according to the manufacturer's instructions.

\section{FACS analysis}

Cells treated with inhibitors were harvested at 5 day pi by trypsinization, centrifuged $(5 \mathrm{~min}, 300 \times g)$, washed with PBS, fixed in $4 \%$ formalin in PBS (15 min, room temperature (RT)) and permeabilized (0.5\% Triton X-100 in PBS, 20 min, RT, Bioshop). Unspecific binding sites were blocked ( $5 \%$ bovine serum albumin (BSA, Bioshop) in PBS, $2 \mathrm{~h} \mathrm{RT}$ ) prior to staining. Further, cells were incubated with anti-coronavirus antibody OC43 strain $(1 \mu \mathrm{g} /$ $\mathrm{mL}$, Merck) for $2 \mathrm{~h}$ and with secondary Alexa Fluor 488 goat anti-mouse antibody $(5 \mu \mathrm{g} / \mathrm{mL}$, Thermo Scientific, 
Poland) for $1 \mathrm{~h}$. Cells were washed with $0.5 \%$ Tween-20, resuspended in PBS, and analyzed with flow cytometry (FACSCalibur, Becton Dickinson).

\section{Confocal microscopy}

Cells cultured on coverslips in 6-well plate for $48 \mathrm{~h}$ were washed with ice-cold PBS and incubated with concentrated $\mathrm{CRCoV}$ at $4{ }^{\circ} \mathrm{C}$ for $60 \mathrm{~min}$ and subsequently incubated at $37{ }^{\circ} \mathrm{C}$ for $0-180 \mathrm{~min}$. Coverslips were washed thrice with PBS, fixed in $4 \%$ formalin for $15 \mathrm{~min}$, permeabilized with $0.5 \%$ Tween-20 (Bioshop) for $20 \mathrm{~min}$ (unless stated otherwise). Unspecific binding sites were blocked using $5 \% \mathrm{BSA}$ in $\mathrm{PBS}\left(4{ }^{\circ} \mathrm{C}\right.$, overnight) prior to staining. For visualization of $\mathrm{CRCoV}$ particles anti-coronavirus antibody OC43 strain ( $1 \mu \mathrm{g} / \mathrm{mL}, 2 \mathrm{~h}, \mathrm{RT}$, Merck) coupled with goat anti-mouse Alexa Fluor 488 antibody $(5 \mu \mathrm{g} /$ $\mathrm{mL}, 1 \mathrm{~h}$, RT, Thermo Scientific) was used. To visualize host cell proteins, cells were blocked using 10\% FBS in PBS ( $4{ }^{\circ} \mathrm{C}$, overnight) and incubated ( $\left.2 \mathrm{~h}, \mathrm{RT}\right)$ with one of the following antibodies: caveolin-1 antibody $(2 \mu \mathrm{g} /$ $\mathrm{mL}$, Santa Cruz Biotechnology), clathrin HC antibody (2 $\mu \mathrm{g} / \mathrm{mL}$, Santa Cruz Biotechnology), EEA1 antibody (2 $\mu \mathrm{g} / \mathrm{mL}$, Santa Cruz Biotechnology), Rab 7 antibody (2 $\mu \mathrm{g} / \mathrm{mL}$, Santa Cruz Biotechnology), endophilin B2 antibody ( $2 \mu \mathrm{g} / \mathrm{mL}$, Santa Cruz Biotechnology), Rab 11 antibody $(2.67 \mu \mathrm{g} / \mathrm{mL}$, Proteintech), LAMP antibody (10 $\mathrm{\mu g} / \mathrm{mL}$, Thermo Scientific) coupled with secondary goat anti-rabbit Alexa Fluor $546(10 \mu \mathrm{g} / \mathrm{mL}$, Thermo Scientific). Signal specificity was verified using isotype control (normal rabbit IgG, normal goat IgG, Santa Cruz Biotechnology). Following this, cells were washed thrice with $0.5 \%$ Tween-20 in PBS. Nuclear DNA was stained with 4',6'-diamidino-2-phenylindole (DAPI, $0.1 \mu \mathrm{g} / \mathrm{mL}$, Sigma-Aldrich). Stained coverslips were mounted on glass slides in Prolong Diamond medium (Thermo Scientific). Fluorescent images were acquired using Zeiss LSM 710 confocal microscope (Carl Zeiss Microscopy GmbH).

\section{Inhibitors influence on initial phase of infection}

Cells pretreated with chemical inhibitors were incubated with concentrated $\mathrm{CRCoV}$ in the presence of inhibitors at $37{ }^{\circ} \mathrm{C}$ for $2 \mathrm{~h}$. Two hours pi cells were washed with PBS twice to remove unbound virus, fixed with $4 \%$ formalin in PBS (15 min, RT) and permeabilized with $0.5 \%$ Tween20. Unspecific binding sites were blocked using 5\% BSA in PBS $\left(4{ }^{\circ} \mathrm{C}\right.$, overnight) prior to staining. $\mathrm{CRCoV}$ was visualized using anti-coronavirus antibody OC43 strain $(1 \mu \mathrm{g} / \mathrm{mL}, 2 \mathrm{~h}, \mathrm{RT}$, Merck) coupled with goat anti-mouse Alexa Fluor 488 antibody $(5 \mu \mathrm{g} / \mathrm{mL}, 1 \mathrm{~h}$, RT, Thermo Scientific). For this study Alexa-Fluor 647 Phalloidin (4 U/mL, $1 \mathrm{~h}$, RT, Thermo Scientific) labeled actin cortex was assumed to indicate cell surface. Nuclear DNA was stained with DAPI $(0.1 \mu \mathrm{g} / \mathrm{mL}$, Sigma-Aldrich) and coverslips were mounted on glass slides in Prolong Diamond medium.

\section{Post-entry inhibitory effects}

Cells were infected with $\mathrm{CRCoV}$ at $\mathrm{TCID}_{50}$ of $400 / \mathrm{mL}$. After $2 \mathrm{~h}$ incubation unbound virus was washed off with PBS and cells were overlaid with culture medium containing chemical inhibitors. Five days pi cells were harvested for further analysis.

\section{Role of furin during the infection}

Cells were infected with $\mathrm{CRCoV}$ at $\mathrm{TCID}_{50}$ of $400 / \mathrm{mL}$. After $2 \mathrm{~h}$ incubation at $37{ }^{\circ} \mathrm{C}$ unbound virus was washed off with PBS and cells were overlaid with culture medium containing decanoyl-RVKR-chloromethyl ketone (decRVKR-CMK). Four days pi cells were fixed, stained and fluorescent images were acquired.

\section{siRNA transfection}

HRT-18G cells were transfected with 25 pmol of caveolin-1 siRNA (sc-29241, Santa Cruz Biotechnology) or scrambled negative control siRNA (sc-44237, Santa Cruz Biotechnology) using lipofectamine RNAiMAX reagent (Thermo Scientific) according to manufacturer's protocol. Two consecutive transfections were performed $24 \mathrm{~h}$ and $48 \mathrm{~h}$ after cell seeding. Subsequently, cells were infected and prepared for imaging.

\section{Computer analysis}

All graphs presented in this work were created using GraphPad Prism 6 software. Significance was estimated using one-way ANOVA with multiple comparisons to virus control. Images obtained from the confocal microscope were deconvolved using AutoQuant X3 and processed in ImageJ Fiji [23]. Co-localization analyses were performed in ImageJ using JACoP plugin [24] where Pearson's and Manders' coefficient were calculated for $3 \mathrm{D}$ cell reconstructions. The bioinformatics analysis was conducted using arginine and lysine propeptide cleavage sites prediction algorithms ProP 1.0 server [25] using the following sequence data: AAO06124.1 (isolate 4182), ABG78748.1 (isolate 4182), ACX46840.1 (strain K9), AFW97360.1 (strain K37), ACX46860.1 (strain K39) and AQT26498.1 (strain BJ232).

\section{Results}

\section{CRCoV enters HRT-18G cells via endocytosis}

Weak bases such as $\mathrm{NH}_{4} \mathrm{Cl}$ were previously described to hamper endosomal entry of viruses, by preventing $\mathrm{pH}$-dependent activation of the fusion protein, subsequently blocking membrane fusion [26]. Treatment of HRT-18G cells with $50 \mathrm{mM} \mathrm{NH}_{4} \mathrm{Cl}$ inhibited replication of $\mathrm{CRCoV}$ (5.9 $\pm 9.9 \%$ of control, Additional file 2), but 


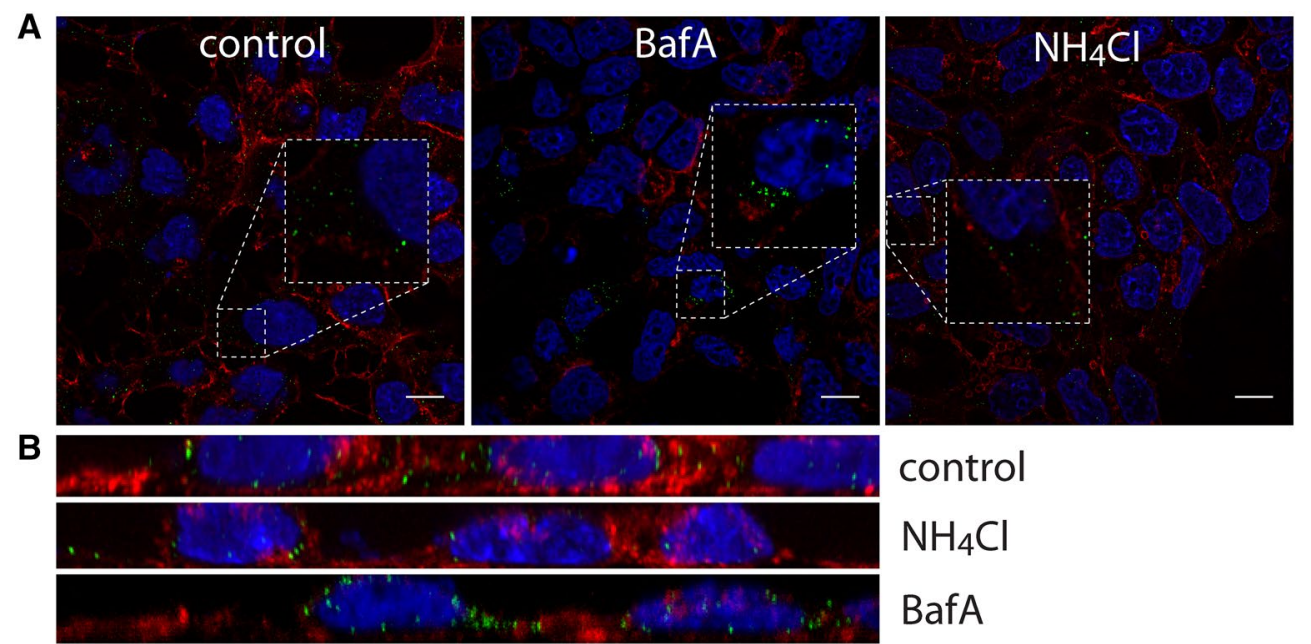

Figure 1 Effect of endosome alkalization on CRCoV infection. A Analysis of inhibitors effect on CRCoV entry, cells were pretreated with inhibitors, infected in presence of them and incubated for $1 \mathrm{~h}$ before they were washed off and fixed. CRCoV virions are presented in green, blue denotes DNA and red represents actin, each image is a single confocal plane while $\mathbf{B}$ represents maximum projections of their axial planes. Scale bar $10 \mu \mathrm{m}$.

did not inhibit virus entry into host cells (Figures 1A and B). Bafilomycin A1 inhibits vacuolar $\mathrm{H}^{+}$-ATPases and blocks endosome acidification [27]. Similarly, bafilomycin A1 blocked virus replication $(93.5 \% \pm 5.2 \%$ reduction in number of infected cells, compared to control) (Additional file 2), but not virus entry (Figures $1 \mathrm{~A}$ and B). Surprisingly, addition of bafilomycin A1 or $\mathrm{NH}_{4} \mathrm{Cl}$ $2 \mathrm{~h}$ pi also resulted in decreased virus replication. Similar observations were made for the most of tested inhibitors of intracellular trafficking (Additional file 2). For this reason we decided to use for the analysis only the data on virus entry.

Consequently, to test whether the virus enters the cell by endocytosis, we examined co-localization of viral particles with early endosome antigen 1 (EEA1) at different times post-infection (pi). Co-localization was clearly visible (Figure 2), peaking at 60-90 min pi (Mander's coefficient $0.63 \pm 0.18$ at $60 \mathrm{~min}$ and $0.64 \pm 0.12$ at $90 \mathrm{~min} \mathrm{pi)}$. No co-localization with the late endosome marker Rab 7, the lysosome marker LAMP1, or the endosome marker Rab 11 was visible at any time (Additional files 3,4 ).

Obtained results suggest that $\mathrm{CRCoV}$ undergoes fusion already in an early endosomal compartment, what may seem contradictory to some previous reports [2, 28-30]. However, some viruses are processed by furin in the producer cell, what makes the processing by cathepsins dispensable [31]. As in silico analysis predicted potential furin cleavage site in $\mathrm{CRCoV}$ spike glycoprotein gene (Additional file 5), effect of dec-RVKR-CMK (5-100 $\mu \mathrm{M}$, Santa Cruz Biotechnology) on virus replication as well as cell-to-cell spread was tested. As visible on Figure 3 no alteration of virus entry was observed.

\section{Inhibition of CRCoV entry into HRT-18G cells}

Next, we used inhibitors of endocytosis to examine the endocytic pathway utilized by CRCoV to enter HRT-18G cell. All inhibitors were used at the highest non-toxic concentration (determined in an XTT assay; data not shown). The validity of the obtained data was verified using positive controls (transferrin, cholera toxin subunit $\mathrm{B}\left(\mathrm{CHT}_{\mathrm{x}} \mathrm{B}\right)$, and dextran), which enter the cell via clathrin-dependent pathway, caveolin-dependent pathway, and macropinocytosis, respectively [9, 32].

To determine whether CRCoV enters HRT-18G cells by clathrin-mediated endocytosis (CME), we treated cells with chlorpromazine, amantadine, or PitStop-2 [33, 34]. None of the compounds affected the virus entry to the cells (Figures $4 \mathrm{~A}$ and $\mathrm{B}$ ).

Caveolae, rich in cholesterol and sphingolipids, are disrupted by sterol-binding agents, as nystatin, filipin, or $\mathrm{M} \beta C D$. Filipin had no effect on virus entry; neither did it hamper internalization of $\mathrm{CHT}_{\mathrm{x}} \mathrm{B}$, implying ineffectiveness of this inhibitor on HRT-18G cell line. Nystatin and $M \beta C D$ blocked virus internalization to the cell (Figures 5A and $\mathrm{B}$ ), suggesting that caveolae are essential during $\mathrm{CRCoV}$ internalization. To ensure that the observed effect is not an artifact, caveolin-1 expression was silenced using siRNAs. As shown in Figure 6, depletion of caveolin-1 resulted in reduction in number of virus particles entering the cell. 


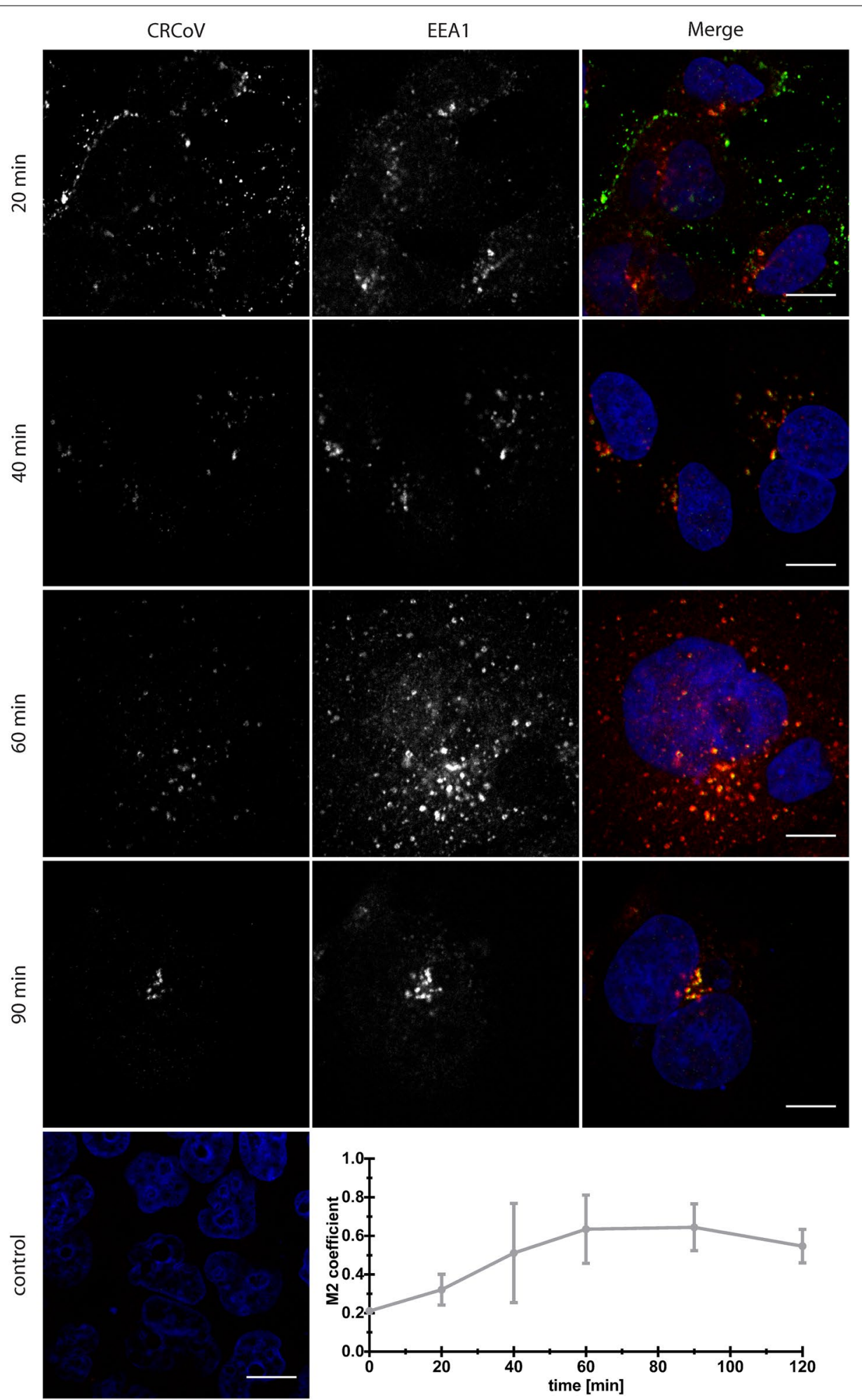

Figure 2 Co-localization of CRCoV with early endosome marker EEA1. Virus treated cells were synchronized on ice for 60 min and incubated at $37^{\circ} \mathrm{C}$ before they were washed and fixed with $4 \%$ paraformaldehyde in PBS. Localization was analyzed by confocal microscopy after performing a double immunofluorescence staining to visualize virus nucleocapsid (left) and early endosomes (middle). Right panel shows merged image with virus presented as green and EEA1 as red. Cell nuclei are shown in blue. Control—negative control, cells incubated with mock sample (green) and stained with isotype antibodies (red). Scale bar $10 \mu \mathrm{m}$. Graph presents co-localization change in time. 
A

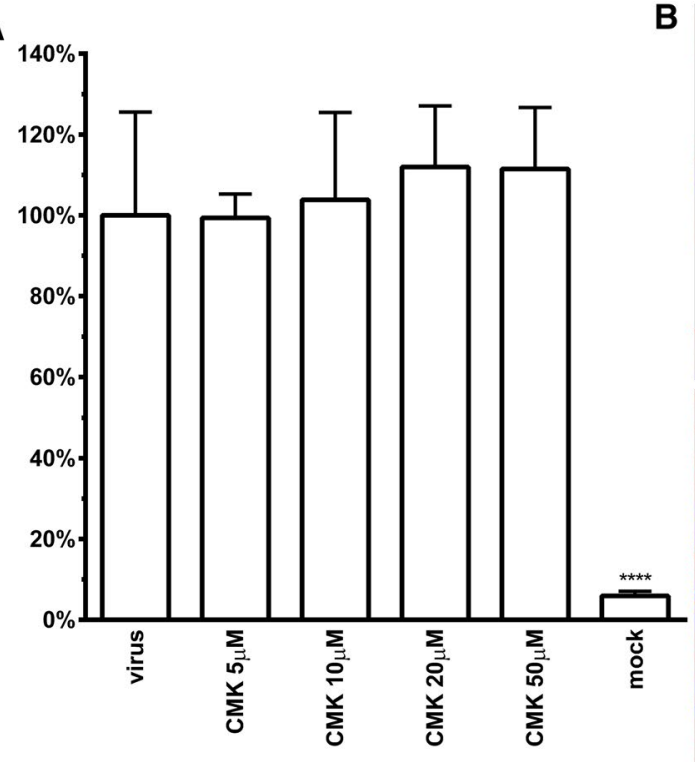

$B$
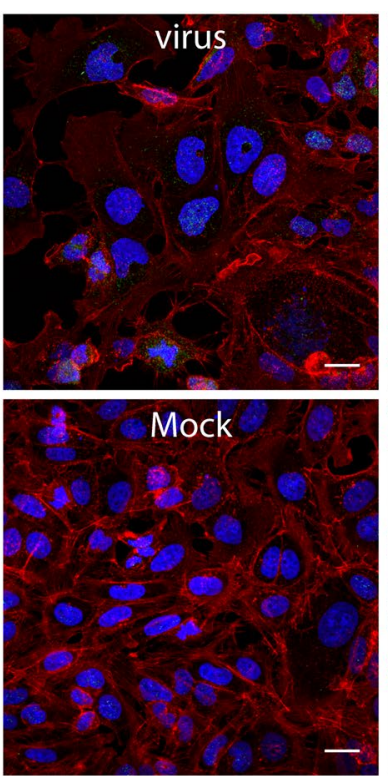
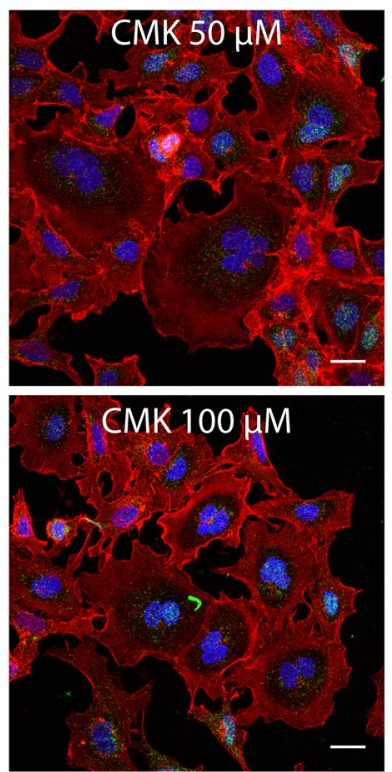

Figure 3 Effect of furin inhibitor-decanoyl-RVKR-chloromethyl ketone (CMK) on CRCoV replication (A) and cell to cell spread (B). A Graph shows number of virus positive cells at $4^{\text {th }}$ day pi normalized to control. HRT-18G cells were pretreated with inhibitor before infection and it was present post-infection. B $3 \mathrm{~h}$ pi cells were overlaid with CMK containing medium and were propagated in this conditions until fixation at $4^{\text {th }}$ day pi. CRCoV virions are presented in green, blue denotes DNA and red represents actin. Scale bar $20 \mu \mathrm{M}$.
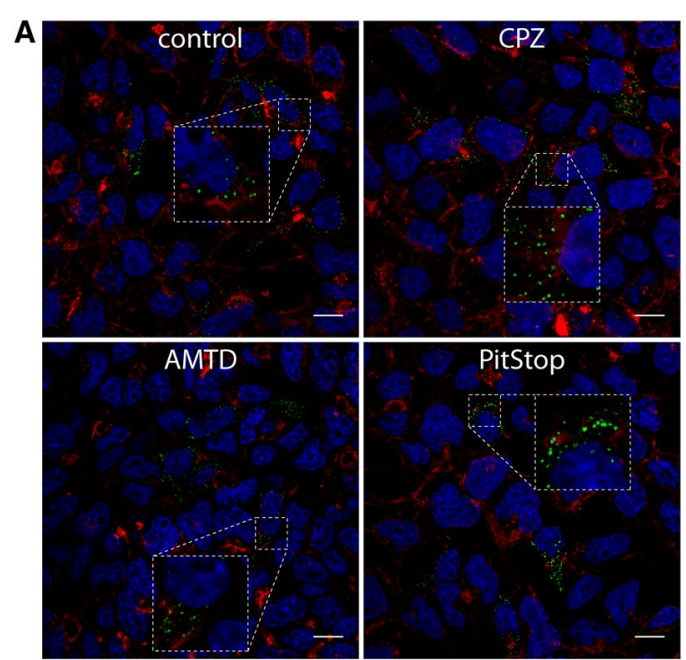

B

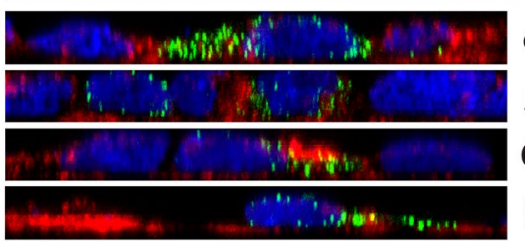

control

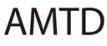

CPZ PitStop

Figure 4 Effect of clathrin-mediated endocytosis inhibitors on CRCoV infection. A Analysis of inhibitors effect on CRCoV entry, cells were pretreated with inhibitors, infected in presence of them and incubated for $1 \mathrm{~h}$ before they were washed off and fixed. CRCoV virions are presented in green, blue denotes DNA and red represents actin, each image is a single confocal plane while $\mathbf{B}$ represents maximum projections of their axial planes. Scale bar $10 \mu \mathrm{m}$.
To check whether the virus enters cells via macropinocytosis, we treated them with the $\mathrm{NA}^{+} / \mathrm{H}^{+}$exchanger inhibitor EIPA, the Pak-1 inhibitor IPA-3, and the PI3K inhibitor wortmannin [35]. No effect on virus entry was, however, observed (Figures 7A and B).

\section{Co-localization of virus particles with markers of endocytic pathways}

The above results showed that only compounds that interfere with caveosome formation affect CRCoV entry. However, some reports show that these compounds have off-target and multi-target activity [36-39]. Therefore, to ensure the validity of the obtained data, we examined co-localization of virus particles with markers of different endocytic pathways. Cells were exposed to virus for 0-180 min. As shown in Figure 8, CRCoV co-localized with caveolin at $20 \mathrm{~min} \mathrm{pi,} \mathrm{and} \mathrm{this} \mathrm{was} \mathrm{maintained} \mathrm{for}$ up to $120 \mathrm{~min}$ pi. Visual assessment and analysis of colocalization coefficients revealed that co-localization was more marked than for $\mathrm{CHT}_{\mathrm{x}} \mathrm{B}$, which utilizes the caveolin-1 mediated pathway to enter cells (Figures $5 \mathrm{C}$ and $8 D)$. We also examined whether the virus co-localizes with clathrin (Figure 9) or endophilin (Additional file 6). No co-localization was detected.

\section{Dynamin is important for CRCoV internalization}

Dynamin is essential for several endocytic pathways [14, 40, 41]. Therefore, we asked whether this GTPase plays 
A
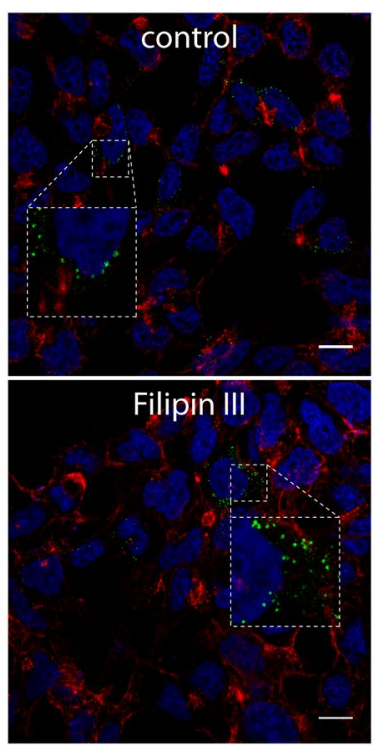
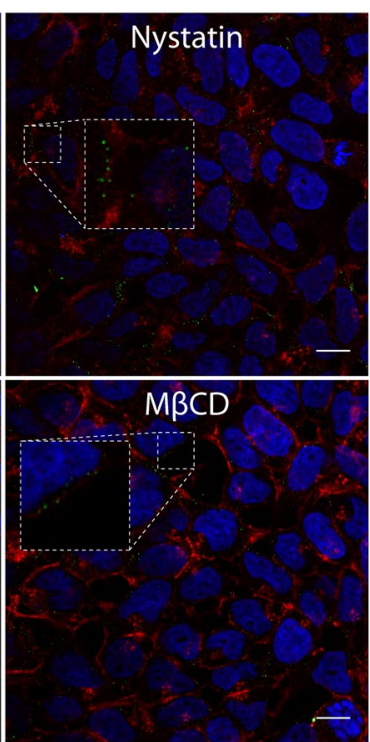

B

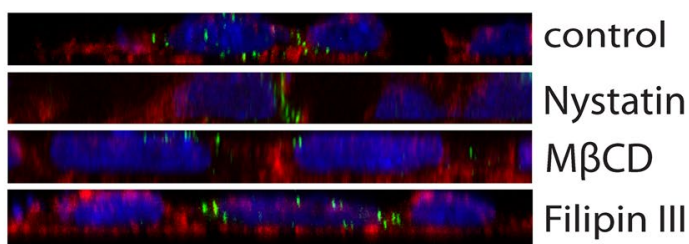

C

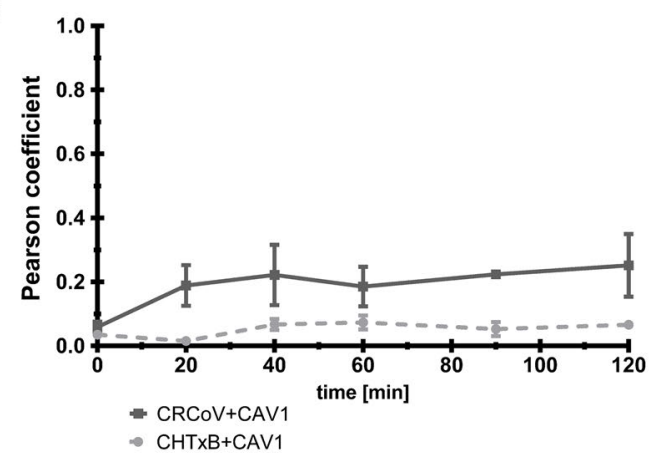

Figure 5 Effect of caveolin-mediated endocytosis inhibitors on CRCoV. A Analysis of inhibitors effect on CRCoV infection, cells were pretreated with inhibitors, infected in presence of them and incubated for $1 \mathrm{~h}$ before they were washed off and fixed. CRCoV virions are presented in green, blue denotes DNA and red represents actin, each image is a single confocal plane while $\mathbf{B}$ represents maximum projections of their axial planes. $\mathbf{C}$ Comparison of CRCoV and CHTxB co-localization with caveolin-1. Scale bar $10 \mu \mathrm{m}$.

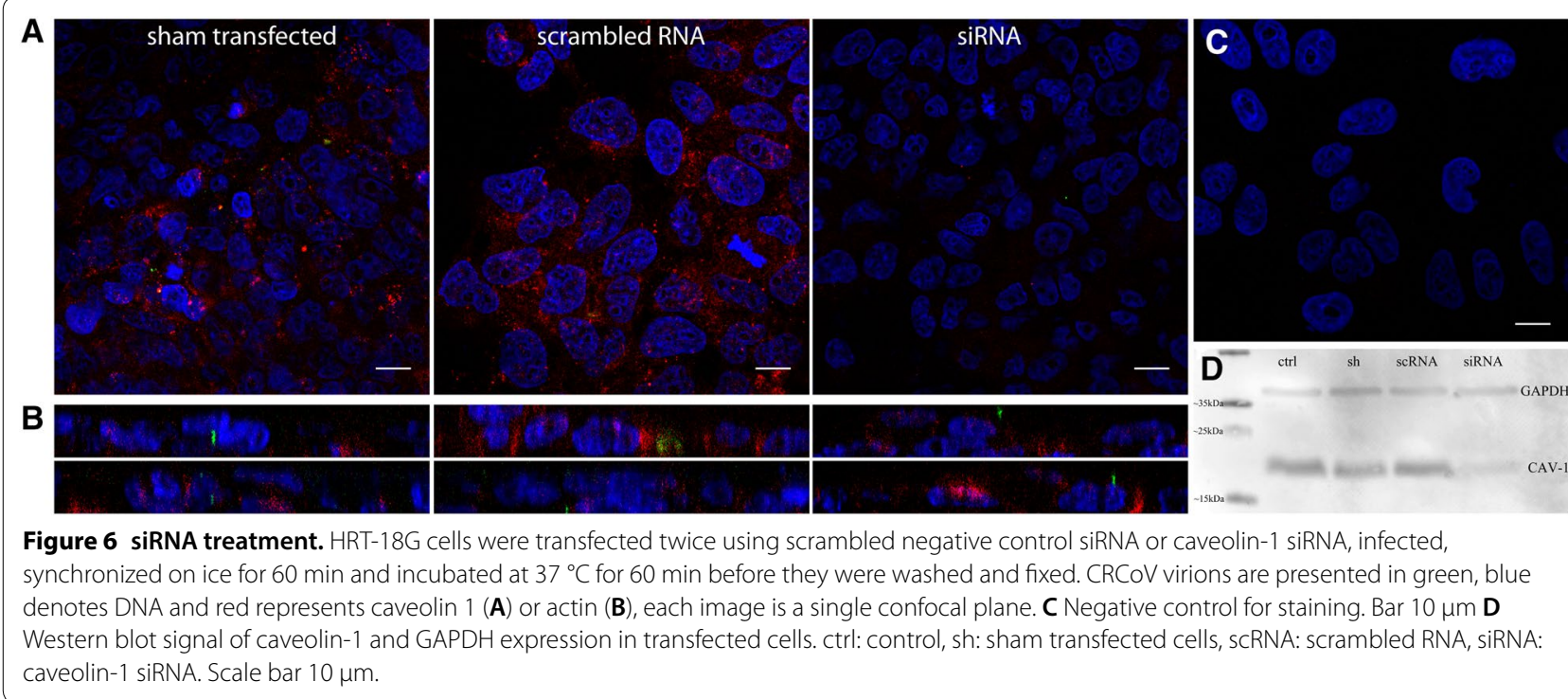

a role in $\mathrm{CRCoV}$ entry into cells. For this, we used three inhibitors of dynamin, which inhibited GTPase activity (dynasore and iminodyn-22) [42, 43] or blocked the lipid binding (MiTMAB) [44]. All three inhibitors affected virus replication: dynasore by $87.8 \pm 7.5 \%$, iminodyn-22 by $60.0 \pm 1.5 \%$, and MiTMAB by $94.1 \pm 3.7 \%$ (Additional file 2) when added before infection. What is even more important, their effect was limited when added only postinfection (Additional file 2), suggesting that dynamin is important at early stages of infection. All inhibitors caused a marked reduction in the number of virions entering the cell (Figures 10A and B). Recently, Xu et al. [45] studied JEV entry into the cells and proposed a new model-actin- and dynamin-dependent caveolae-mediated endocytosis. Thus, we analyzed the effect of inhibiting Rho, Rac1, and ROCK kinases on virus infection. Only inhibition of Rac1 (by NSC23766) hampered viral replication showing significantly stronger effect when 


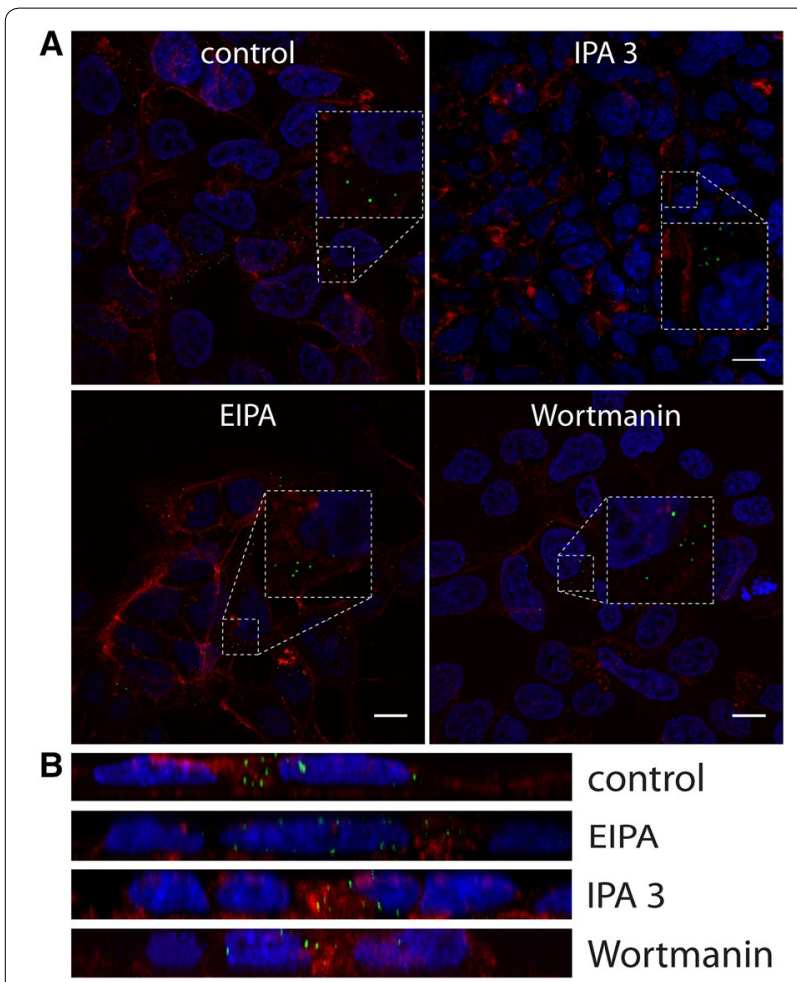

Figure 7 Effect of macropinocytosis inhibitors on CRCoV infection. A Analysis of inhibitors effect on CRCoV entry, cells were pretreated with inhibitors, infected in presence of them and incubated for $1 \mathrm{~h}$ before they were washed off and fixed. CRCoV virions are presented in green, blue denotes DNA and red represents actin, each image is a single confocal plane while $\mathbf{B}$ represents maximum projections of their axial planes. Scale bar $10 \mu \mathrm{m}$.

present prior to infection $(7.9 \% \pm 9.3$ of control) than after $(51.9 \% \pm 3.6$ of control) (Additional file 2$)$ implying its involvement in entry process.

\section{Cytoskeleton}

The results so far suggest that CRCoV enters HRT-18G cells via caveolin- and dynamin-dependent endocytosis, and that it is likely that fusion occurs early after internalization. Therefore, we examined the role of the cytoskeleton during virus entry. First, we evaluated the effect of an actin-disrupting agent (cytochalasin D), an actin stabilizing compound (jasplakinolide), and an inducer of microtubule depolimerization (nocodazole) [46, 47]. Additional file 2 shows that, while microtubules are not important for virus infection, actin plays a central role during the early stages of $\mathrm{CRCoV}$ infection. Disrupting actin filaments led to a reduction (by $84.5 \% \pm 8.9$ ) in viral infection, although filament stabilization had no effect on virus yield. Lack of this effect after post-entry treatment (Additional file 2) imply that actin is required during early events of $\mathrm{CRCoV}$ infection. Studies of virus localization revealed that after treatment with cytochalasin D, multiple viral particles localize to actin aggregates (Figures $11 \mathrm{~A}$ and $\mathrm{B}$ ); this implies that an intact actin cytoskeleton plays a role in intracellular transport of viruses.

\section{Discussion}

To propagate, viruses need to deliver their genetic material into the host cell. To do this, enveloped viruses fuse with the cellular membrane prior to ejecting genomic RNA or DNA into the cytoplasm. This may take place on the cell surface or after endocytosis. Here, we identified the pathway by which $\mathrm{CRCoV}$ enters human epithelial cells (HRT-18G) [8].

First, we asked whether $\mathrm{CRCoV}$ enters cells via endocytosis. Sensitivity to lysosomotropic agents is considered good evidence of endocytosis [48]; therefore, we treated cells with inhibitors of endosome acidification (bafilomycin $\mathrm{A}$ and ammonium chloride). Both compounds hampered virus infection, suggesting that $\mathrm{CRCoV}$ enters HRT-18G cells via endocytosis rather than via direct membrane fusion. However, inhibitory effect of inhibitors altering the endosomal $\mathrm{pH}$ was observed also on the replication stage. Similar phenomenon was previously reported for SARS-CoV [49]. It was suggested that these compounds interfere with glycosylation of the viral proteins and in such a way suppress their expression and assembly $[49,50]$. Nonetheless, we decided to present the data on virus replication in supplementary material and focus on virus entry to the cell.

No single pathway of entry has been reported for Coronaviridae. Indeed, studies have identified clathrindependent, caveolin-dependent, clathrin-and-caveolinindependent, and endocytosis-independent routes (see Table 1). To identify the route of entry used by CRCoV, we utilized inhibitors of several different pathways (see Additional file 1). However, it is worth remembering that chemical inhibitors may affect other phases of virus replication by interfering with viral and cellular proteins (e.g., kinases, GTPases) [32, 51]. Indeed, we observed such non-specific interaction and consequently it was not possible to test the effect of chemical inhibitors on virus replication, as virus yields were reduced by almost all compounds affecting intracellular trafficking. To further address this issue, we employed complementary approaches: siRNA-mediated knockdown of caveolin-1 and analysis of co-localization of $\mathrm{CRCoV}$ viral particles with markers of different intracellular compartments. 


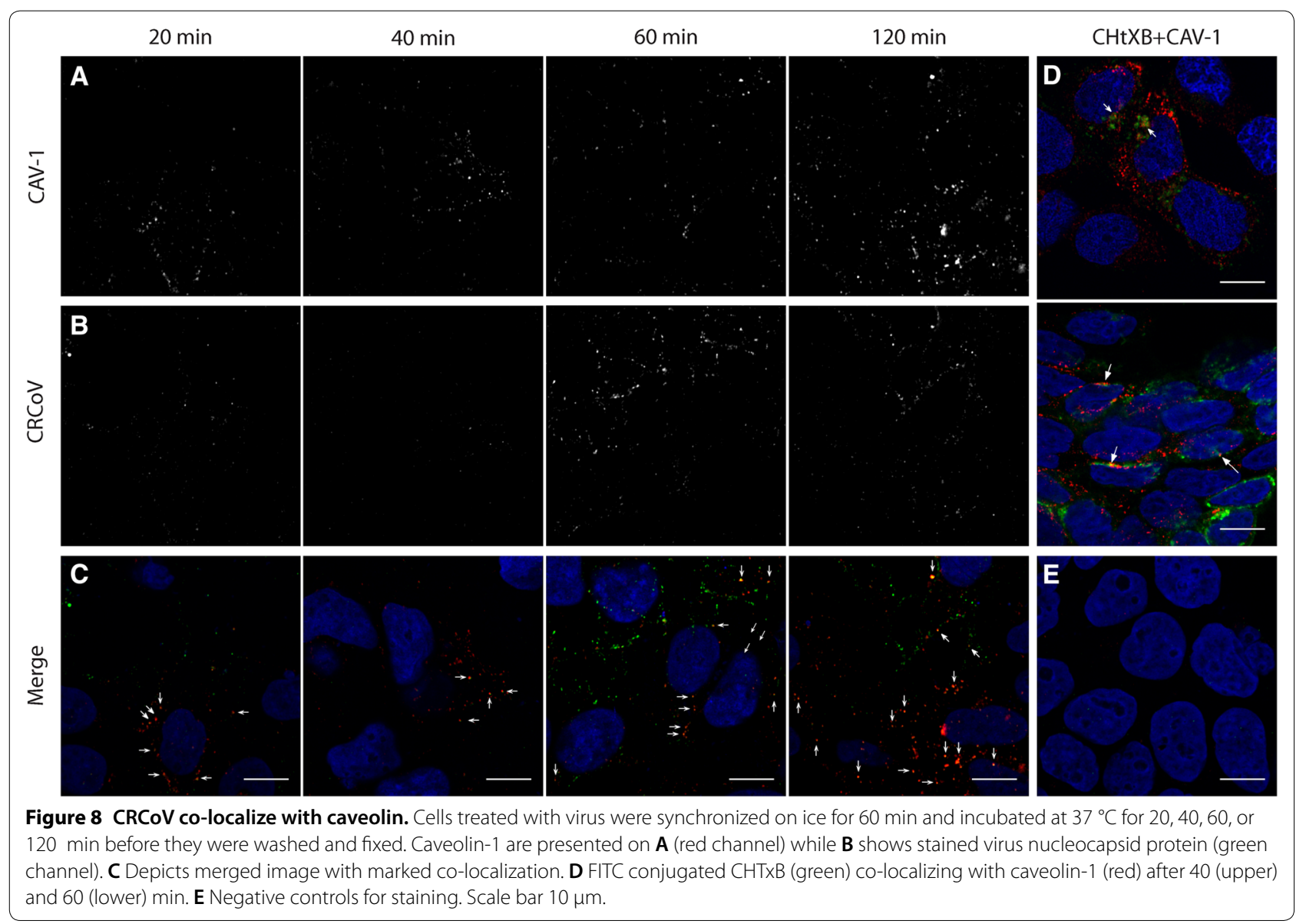

The results revealed that $\mathrm{CRCoV}$ enters the cell via the caveolin-1 dependent pathway; indeed, CRCoV particles co-localized with endosomes coated with caveolin-1, but not with clathrin or endophilin (Additional file 6). Furthermore, siRNA-mediated depletion of caveolin-1 inhibited virus entry.

Next, we focused on dynamin, an important GTPase involved in vesicle scission during endocytosis. While it is most commonly associated with clathrin-mediated endocytosis, it also plays a role in phagocytosis and caveolin-1, ILR-2-, and flotillin-dependent endocytosis $[14,40,41]$. To do this, we used three dynamin inhibitors, two that inhibit GTPase activity and one that blocks the lipid-binding domain of dynamin. The results led us to conclude that CRCoV entry into HRT-18G cells is dynamin-dependent.

In order to monitor intracellular trafficking of $\mathrm{CRCoV}$ and to determine the specific point of virus-cell membrane fusion, we examined co-localization of the $\mathrm{CRCoV}$ nucleocapsid protein and endosomal vesicle markers. The results showed that $\mathrm{CRCoV}$ was present in early endosomes but absent from late and recycling endosomes and lysosomes. This indicates that fusion of CRCoV and cellular membranes occurs at an early stage, before the endosome recruit Rab 7 and progresses to the late phase. This is different from the majority of coronaviruses, which travel far along the endocytic pathway to access high cathepsin activity (e.g., SARS-CoV, MHV, FIPV, porcine epidemic diarrhea coronavirus) [2, 28, 30]. The pathway used by CRCoV is more similar to that used by MERS-CoV reported to utilize furin as well as transmembrane protease serine 2 (TMPRSS2) [2, 17, 28, 29, $31]$. We tested the influence of furin inhibitor decanoylRVKR-chloromethyl ketone in order to study the importance of furin for CRCoV entry. No inhibition of virus replication or cell to cell spread was noted, showing that furin processing is not relevant for CRCoV entry. One may however speculate that regardless of fusion with the host membrane occurring early after internalization, $\mathrm{CRCoV}$ may still utilize cathepsins similarly to most 


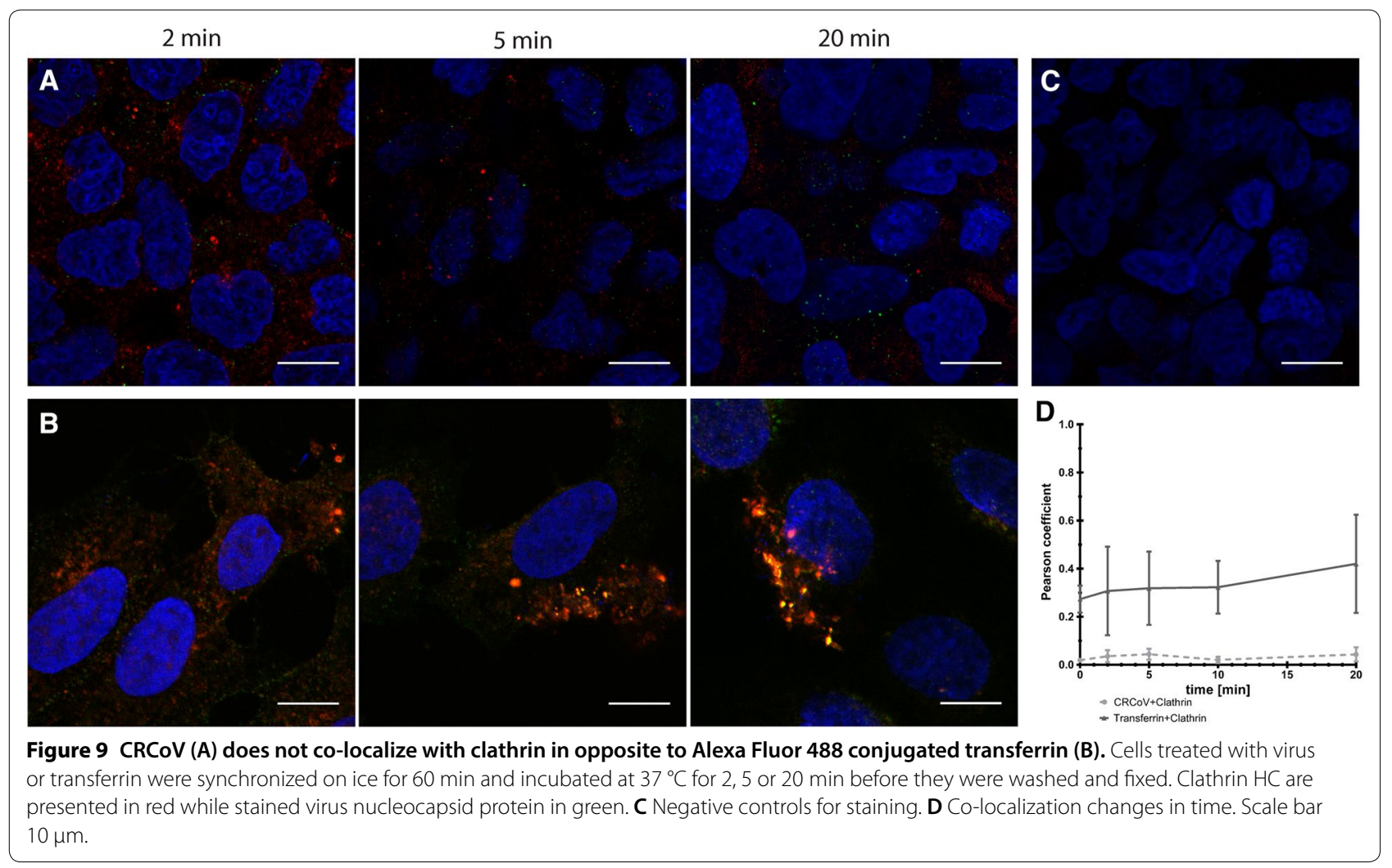

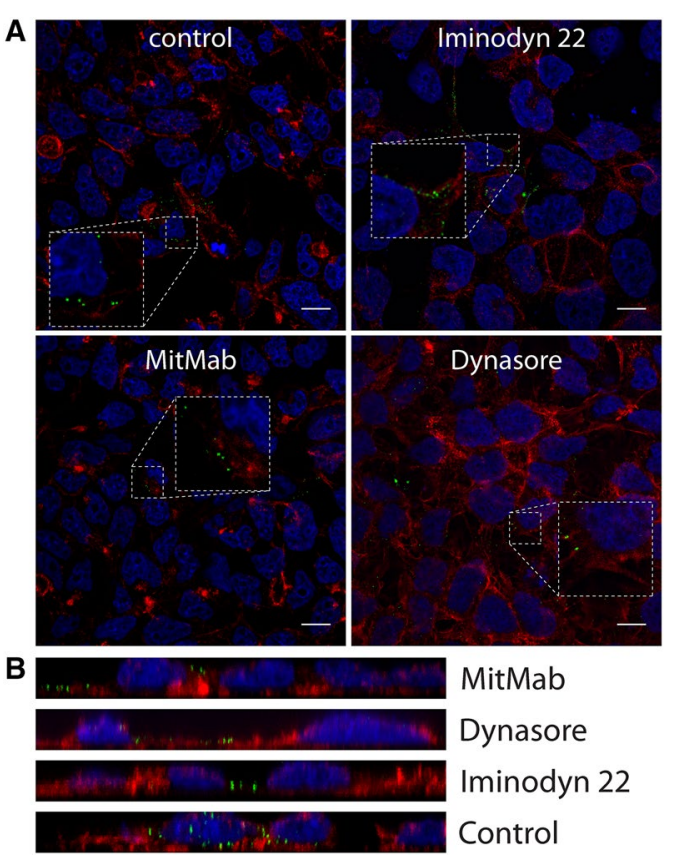

Figure 10 Vesicle scission-dynamin dependence. A Analysis of inhibitors effect on CRCoV entry, cells were pretreated with inhibitors, infected in presence of them and incubated for $1 \mathrm{~h}$ before they were washed off and fixed. CRCoV virions are presented in green, blue denotes DNA and red represents actin, each image is a single confocal plane while $\mathbf{B}$ represents maximum projections of their axial planes. Scale bar $10 \mu \mathrm{m}$. coronaviruses. Even if cathepsins is considered to require acidic $\mathrm{pH}$ for activation this dependency varies according to substrate and so far a few substrates were described to be cleaved in slightly acidic $\mathrm{pH}$ comparable to that achieved before endosome maturation [52-54]. Another potential explanation is cleavage by other proteases such as cell surface TMPRSS2 recently reported to be preferred over cathepsins by several coronaviruses $[18,29]$.

Our last objective was to study the role of the cytoskeleton during $\mathrm{CRCoV}$ infection. We discovered that in cells treated with cytochalasin D prior to infection, virus replication was reduced and during entry the virions accumulated on actin aggregates. Surprisingly, another actin inhibitor, jasplakinolide, had no significant effect on virus replication or entry. Interestingly, cytochalasin D and jasplakinolide affect the actin cytoskeleton via opposing mechanisms: cytochalasin $\mathrm{D}$ inhibits polymerization of actin subunits, whereas jasplakinolide stabilizes filaments by inhibiting depolymerization $[46,55]$. The results obtained using these two agents suggest that actin filaments, but not actin reorganization, are required for CRCoV entry.

Coronaviruses are a family of viruses with high zoonotic potential. As such, they present a real threat to the global economy and to public health [4,56-58]. Here, we show that CRCoV relies on dynamin-dependent, 

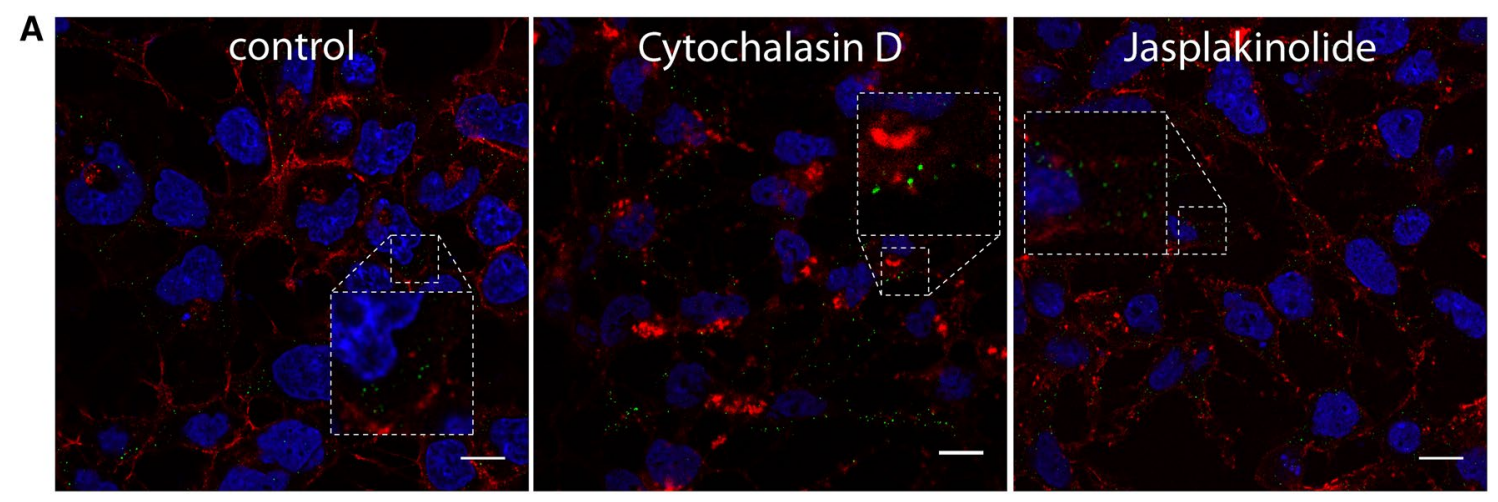

B

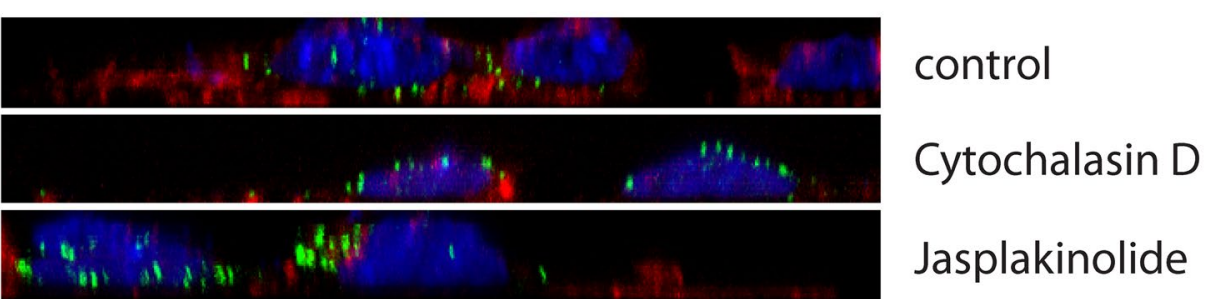

Figure 11 Effect of cytoskeleton reorganization on CRCoV entry. A Analysis of inhibitors effect on CRCoV entry, cells were pretreated with inhibitors, infected in presence of them and incubated for $1 \mathrm{~h}$ before they were washed off and fixed. CRCoV virions are presented in green, blue denotes DNA and red represents actin, each image is a single confocal plane while $\mathbf{B}$ presents maximum projection of their axial planes. Scale bar $10 \mu \mathrm{m}$.

\section{Table 1 Entry pathways described for Coronaviruses}

\begin{tabular}{|c|c|c|c|c|}
\hline Virus & Genus & Entry route & Cells & References \\
\hline \multirow[t]{4}{*}{ HCoV-229E } & \multirow[t]{4}{*}{ Alpha } & pH dependent endocytosis & $\begin{array}{l}\text { Caco-2 (human colon adenocarcinoma), } \\
\text { MRC-5 (human lungs) }\end{array}$ & [59] \\
\hline & & $\begin{array}{l}\text { Caveolin-dependent endocytosis, lipid raft } \\
\text { mediated }\end{array}$ & $\begin{array}{l}\text { Human primary fibroblasts, L132 (human } \\
\text { embryonic lung cell line) }\end{array}$ & [15] \\
\hline & & $\begin{array}{l}\text { Endocytosis_laboratory strains, membrane } \\
\text { fusion_clinical isolates }\end{array}$ & $\begin{array}{l}\text { HeLa-229 (human cervix), HAE (human } \\
\text { airway epithelium) }\end{array}$ & [18] \\
\hline & & Membrane fusion & $\begin{array}{l}\text { HEK 293T (human embryonic kidney), } \\
\text { Caco-2 (human colon adenocarcinoma) }\end{array}$ & [16] \\
\hline HCoV-NL63 & Alpha & Clathrin-dependent endocytosis & $\begin{array}{l}\text { LLC-MK2 (rhesus monkey kidney) HAE } \\
\text { (human airway epithelium) }\end{array}$ & [60] \\
\hline Feline infectious peritonitis & Alpha & Clathrin- and caveolin-independent endocytosis & Primary feline monocytes & [14] \\
\hline Transmissible gastroenteritis virus & Alpha & Lipid raft mediated & ST (swine testicles) & [61] \\
\hline Canine enteric Coronavirus & Alpha & Lipid raft mediated & A72 (canine fibroma) & [62] \\
\hline \multirow[t]{3}{*}{ Mouse hepatitis virus } & \multirow[t]{3}{*}{ Beta } & Cell membrane fusion & Mouse 3T3-L2 fibroblast & [63] \\
\hline & & pH dependent endocytosis & Murine fibroblast & [64] \\
\hline & & Lipid raft mediated & DBT cells (mouse astrocytoma) & [65] \\
\hline \multirow[t]{5}{*}{ SARS-CoV } & \multirow[t]{5}{*}{ Beta } & Clathrin-dependent endocytosis & HepG2 (human hepatoma) & [13] \\
\hline & & Membrane fusion & Vero E6 (African green monkey kidney) & [66] \\
\hline & & Lipid raft mediated & Vero E6 (African green monkey kidney) & [11] \\
\hline & & $\begin{array}{l}\text { Clathrin- and caveolin-independent endocy- } \\
\text { tosis }\end{array}$ & $\begin{array}{l}\text { HEK } 293 \text { E (human embryonic kidney), Vero } \\
\text { E6 (African green monkey kidney) }\end{array}$ & [12] \\
\hline & & Membrane fusion & $\begin{array}{l}\text { Vero E6 (African green monkey kidney), HEK } \\
\text { 293T (human embryonic kidney) }\end{array}$ & [67] \\
\hline MERS-COV & Beta & Virus-cell fusion & $\begin{array}{l}\text { HEK 293T (human embryonic kidney), } \\
\text { Caco-2 (human colon adenocarcinoma) }\end{array}$ & [17] \\
\hline HCoV-OC43 & Beta & Caveolin-dependent endocytosis & HCT-8 (human adenocarcinoma) & [68] \\
\hline \multirow[t]{2}{*}{ Avian infectious bronchitis virus } & \multirow[t]{2}{*}{ Gamma } & Low-pH-dependent virus-cell fusion & BHK (hamster kidney) & [69] \\
\hline & & Lipid raft mediated & Vero (African green monkey kidney) & [70] \\
\hline
\end{tabular}


caveolin-1-mediated endocytosis to enter host cells. Moreover, we showed that fusion with the host membrane occurs early after internalization.

\section{Additional files}

\section{Additional file 1. Inhibitors of endocytosis and their modes of action.}

The table consists of a list of inhibitors used in this study with detailed information regarding their provider and applied concentration.

\section{Additional file 2. Chemical inhibitors effect on CRCoV infection.} Graphs shows number of virus positive cells at $5^{\text {th }}$ day pi normalized to control. HRT-18G cells were treated with acidification (A), dynamin (B), cell kinases (C), cytoskeleton (D), clathrin (E), macropinocytosis $(\mathrm{F})$ and caveolin $(\mathrm{G})$ inhibitors. Compounds were present prior and during the infection (white) or only after infection (gray). Cells were propagated in their presence until harvested.

\section{Additional file 3. Co-localization of CRCoV with markers of late} endosomes and lysosomes. A. CRCoV do not co-localize with late endosomes marker Rab7. B. CRCoV do not co-localize with lysosome marker LAMP1. C. Negative control D. Co-localization change in time. Cells treated with virus were synchronized on ice for $60 \mathrm{~min}$ and incubated at

$37^{\circ} \mathrm{C}$ before they were washed and fixed. Rab7 and LAMP1 are presented in red and CRCoV nucleocapsid protein in green. Cell nuclei are blue. Scale bar $10 \mu \mathrm{m}$

\section{Additional file 4. CRCoV do not co-localize with recycling endosomes} marker Rab11. Cells treated with virus were synchronized on ice for 60 min and incubated at $37^{\circ} \mathrm{C}$ before they were washed and fixed. Rab11 are presented in red and $\mathrm{CRCoV}$ nucleocapsid protein in green. Cell nuclei are blue. Scale bar $10 \mu \mathrm{m}$. Graph presents co-localization change in time.

Additional file 5. Potential furin cleavage site prediction Graphs show potential furin cleavage sites in the spike protein sequence of $\mathrm{CRCoV}$ isolate $4182(\mathbf{A}, \mathbf{B}), \mathrm{K} 9$ strain (C), K37 strain (D), K39 strain (E) and BJ232 strain $(\mathbf{F})$.

\section{Additional file 6. CRCoV do not co-localize with endophilin. Cells} treated with virus were synchronized on ice for $60 \mathrm{~min}$ and incubated at $37^{\circ} \mathrm{C}$ before they were washed and fixed. Endophilin are presented in red and CRCoV nucleocapsid protein in green. Cell nuclei are blue. Scale bar $10 \mu \mathrm{m}$. Graph presents co-localization change in time.

\section{Abbreviations}

CRCoV: canine respiratory coronavirus; EEA1: early endosome antigen 1; MERS-CoV: Middle East respiratory syndrome coronavirus; HCoVs: human coronaviruses; SARS-CoV: severe acute respiratory syndrome coronavirus; CIRD: canine infectious respiratory disease; $\mathrm{BCoV}$ : bovine coronavirus; $\mathrm{CECoV}$ : canine enteric coronavirus; FIPV: feline infectious peritonitis virus; $\mathrm{TCID}_{50}$ : tissue culture infectious dose; $\mathrm{BSA}$ : bovine serum albumin; $\mathrm{CHT}$ B: cholera toxin subunit B; $M \beta C D$ : methyl- $\beta$-cyclodextrin; EIPA: 5 -(N-ethyl-N-isopropyl) amiloride; AMTD: 1-aminoadamantane.

\section{Competing interests}

The authors declare that they have no competing interests.

\section{Authors' contributions}

AS conducted the experiments. KO and AM participated in method development for the study. ZB and ZR participated in confocal imaging. JAM provided cells and viruses. AS and KP designed the study, analyzed the results and wrote the manuscript. All authors read and approved the final manuscript.

\section{Acknowledgements}

This work was supported by the Grants from the National Science Center UMO-2012/07/E/NZ6/01712 to KP and UMO-2017/25/N/NZ6/01310 to KO. KP would like to acknowledge networking contribution by the COST Action CM1407 "Challenging organic syntheses inspired by nature-from natural products chemistry to drug discovery". The Faculty of Biochemistry, Biophysics and Biotechnology of the Jagiellonian University is a beneficiary of the structural funds from the European Union (Grant No: POIG.02.01.00-12-475 064/08- "Molecular biotechnology for health"). Faculty of Biochemistry, Biophysics and Biotechnology of the Jagiellonian University is a partner of the Leading National Research Center supported by the Ministry of Science and Higher Education of the Republic of Poland. The funders had no role in study design, data collection and analysis, decision to publish, or preparation of the manuscript.

\section{Author details}

${ }^{1}$ Virogenetics, Malopolska Centre of Biotechnology, Jagiellonian University, Krakow, Poland. ${ }^{2}$ Faculty of Biochemistry, Biophysics and Biotechnology, Jagiellonian University, Krakow, Poland. ${ }^{3}$ Institute of Physics, Faculty of Physics, Astronomy and Applied Computer Sciences, Jagiellonian University, Lojasiewicza 11, 30-348 Krakow, Poland. ${ }^{4}$ Department of Pathology and Pathogen Biology, The Royal Veterinary College, Hatfield, Hertfordshire AL9 7TA, UK.

\section{Publisher's Note}

Springer Nature remains neutral with regard to jurisdictional claims in published maps and institutional affiliations.

Received: 14 February 2018 Accepted: 14 June 2018

Published online: 03 July 2018

\section{References}

1. King MQA, Adams MJ, Carstens EB, Lefkowitz EJ (2012) Virus taxonomy classification and nomenclature of viruses

2. Burkard C, Verheije MH, Wicht O, van Kasteren SI, van Kuppeveld FJ, Haagmans BL, Pelkmans L, Rottier PJ, Bosch BJ, de Haan CA (2014) Coronavirus cell entry occurs through the endo-/lysosomal pathway in a proteolysisdependent manner. PLoS Pathog 10:e1004502

3. Zaki AM, van Boheemen S, Bestebroer TM, Osterhaus AD, Fouchier RA (2012) Isolation of a novel coronavirus from a man with pneumonia in Saudi Arabia. N Engl J Med 367:1814-1820

4. Mackay IM, Arden KE (2015) MERS coronavirus: diagnostics, epidemiology and transmission. Virol J 12:222

5. Erles K, Toomey C, Brooks HW, Brownlie J (2003) Detection of a group 2 coronavirus in dogs with canine infectious respiratory disease. Virology 310:216-223

6. Mitchell JA, Brooks HW, Szladovits B, Erles K, Gibbons R, Shields S, Brownlie J (2013) Tropism and pathological findings associated with canine respiratory coronavirus (CRCoV). Vet Microbiol 162:582-594

7. Priestnall SL, Brownlie J, Dubovi EJ, Erles K (2006) Serological prevalence of canine respiratory coronavirus. Vet Microbiol 115:43-53

8. Erles K, Brownlie J (2008) Canine respiratory coronavirus: an emerging pathogen in the canine infectious respiratory disease complex. Vet Clin North Am Small Anim Pract 38:815-825

9. Heikkila O, Susi P, Tevaluoto T, Harma H, Marjomaki V, Hyypia T, Kiljunen S (2010) Internalization of coxsackievirus A9 is mediated by \{beta\}2microglobulin, dynamin, and Arf6 but not by caveolin-1 or clathrin. J Virol 84:3666-3681

10. Marsh M, Helenius A (2006) Virus entry: open sesame. Cell 124:729-740

11. Li GM, Li YG, Yamate M, Li SM, Ikuta K (2007) Lipid rafts play an important role in the early stage of severe acute respiratory syndrome-coronavirus life cycle. Microbes Infect 9:96-102

12. Wang H, Yang P, Liu K, Guo F, Zhang Y, Zhang G, Jiang C (2008) SARS coronavirus entry into host cells through a novel clathrin- and caveolaeindependent endocytic pathway. Cell Res 18:290-301

13. Inoue $Y$, Tanaka N, Tanaka Y, Inoue S, Morita K, Zhuang M, Hattori T, Sugamura K (2007) Clathrin-dependent entry of severe acute respiratory syndrome coronavirus into target cells expressing ACE2 with the cytoplasmic tail deleted. J Virol 81:8722-8729

14. Van Hamme E, Dewerchin HL, Cornelissen E, Verhasselt B, Nauwynck HJ (2008) Clathrin- and caveolae-independent entry of feline infectious peritonitis virus in monocytes depends on dynamin. J Gen Virol 89:2147-2156 
15. Nomura R, Kiyota A, Suzaki E, Kataoka K, Ohe Y, Miyamoto K, Senda T, Fujimoto T (2004) Human coronavirus 229E binds to CD13 in rafts and enters the cell through caveolae. JVirol 78:8701-8708

16. Bertram S, Dijkman R, Habjan M, Heurich A, Gierer S, Glowacka I, Welsch K, Winkler M, Schneider H, Hofmann-Winkler H, Thiel V, Pohlmann S (2013) TMPRSS2 activates the human coronavirus $229 \mathrm{E}$ for cathepsin-independent host cell entry and is expressed in viral target cells in the respiratory epithelium. J Virol 87:6150-6160

17. Gierer S, Bertram S, Kaup F, Wrensch F, Heurich A, Kramer-Kuhl A, Welsch K, Winkler M, Meyer B, Drosten C, Dittmer U, von Hahn T, Simmons G, Hofmann H, Pohlmann S (2013) The spike protein of the emerging betacoronavirus EMC uses a novel coronavirus receptor for entry, can be activated by TMPRSS2, and is targeted by neutralizing antibodies. J Virol 87:5502-5511

18. Shirato K, Kanou K, Kawase M, Matsuyama S (2017) Clinical isolates of human coronavirus 229E bypass the endosome for cell entry. JVirol 91:e01387-e01416

19. Mainou BA, Dermody TS (2012) Transport to late endosomes is required for efficient reovirus infection. J Virol 86:8346-8358

20. Girard E, Chmiest D, Fournier N, Johannes L, Paul JL, Vedie B, Lamaze C (2014) Rab7 is functionally required for selective cargo sorting at the early endosome. Traffic 15:309-326

21. Somsel Rodman J, Wandinger-Ness A (2000) Rab GTPases coordinate endocytosis. J Cell Sci 113:183-192

22. Reed $L$, Muench $H$ (1938) A simple method of estimating fifty per cent endpoints. Am J Epidemiol 27:493-497

23. Schindelin J, Arganda-Carreras I, Frise E, Kaynig V, Longair M, Pietzsch T, Preibisch S, Rueden C, Saalfeld S, Schmid B, Tinevez JY, White DJ, Hartenstein V, Eliceiri K, Tomancak P, Cardona A (2012) Fiji: an open-source platform for biological-image analysis. Nat Methods 9:676-682

24. Bolte S, Cordelieres FP (2006) A guided tour into subcellular colocalization analysis in light microsc. J Microscopy 224:213-232

25. Duckert P, Brunak S, Blom N (2004) Prediction of proprotein convertase cleavage sites. Protein Eng Des Sel 17:107-112

26. Qian Z, Dominguez SR, Holmes KV (2013) Role of the spike glycoprotein of human Middle East respiratory syndrome coronavirus (MERS-CoV) in virus entry and syncytia formation. PLoS One 8:e76469

27. Bowman EJ, Siebers A, Altendorf K (1988) Bafilomycins: a class of inhibitors of membrane ATPases from microorganisms, animal cells, and plant cells. Proc Natl Acad Sci U S A 85:7972-7976

28. Huang IC, Bosch BJ, Li F, Li W, Lee KH, Ghiran S, Vasilieva N, Dermody TS, Harrison SC, Dormitzer PR, Farzan M, Rottier PJ, Choe H (2006) SARS coronavirus, but not human coronavirus NL63, utilizes cathepsin L to infect ACE2-expressing cells. J Biol Chem 281:3198-3203

29. Shirato K, Kawase M, Matsuyama S (2018) Wild-type human coronaviruses prefer cell-surface TMPRSS2 to endosomal cathepsins for cell entry. Virology 517:9-15

30. Liu C, Ma Y, Yang Y, Zheng Y, Shang J, Zhou Y, Jiang S, Du L, Li J, Li F (2016) Cell entry of porcine epidemic diarrhea coronavirus is activated by lysosomal proteases. J Biol Chem 291:24779-24786

31. Millet JK, Whittaker GR (2014) Host cell entry of Middle East respiratory syndrome coronavirus after two-step, furin-mediated activation of the spike protein. Proc Natl Acad Sci U S A 111:15214-15219

32. Pelkmans L, Helenius A (2002) Endocytosis via caveolae. Traffic 3:311-320

33. Phonphok Y, Rosenthal KS (1991) Stabilization of clathrin coated vesicles by amantadine, tromantadine and other hydrophobic amines. FEBS Lett 281:188-190

34. Wang LH, Rothberg KG, Anderson RG (1993) Mis-assembly of clathrin lattices on endosomes reveals a regulatory switch for coated pit formation. J Cell Biol 123:1107-1117

35. Lim JP, Gleeson PA (2011) Macropinocytosis: an endocytic pathway for internalising large gulps. Immunol Cell Biol 89:836-843

36. Liu C, Wang J, Zhang X (2014) The involvement of MiR-1-clathrin pathway in the regulation of phagocytosis. PLoS One 9:e98747

37. Ares GR, Ortiz PA (2012) Dynamin2, clathrin, and lipid rafts mediate endocytosis of the apical $\mathrm{Na} / \mathrm{K} / 2 \mathrm{Cl}$ cotransporter NKCC2 in thick ascending limbs. J Biol Chem 287:37824-37834

38. Dutta D, Williamson CD, Cole NB, Donaldson JG (2012) Pitstop 2 is a potent inhibitor of clathrin-independent endocytosis. PLoS One 7:e45799

39. von Kleist L, Stahlschmidt W, Bulut H, Gromova K, Puchkov D, Robertson MJ, MacGregor KA, Tomilin N, Pechstein A, Chau N, Chircop M, Sakoff
J, von Kries JP, Saenger W, Krausslich HG, Shupliakov O, Robinson PJ, McCluskey A, Haucke V (2011) Role of the clathrin terminal domain in regulating coated pit dynamics revealed by small molecule inhibition. Cell 146:471-484

40. Henley JR, Krueger EW, Oswald BJ, McNiven MA (1998) Dynamin-mediated internalization of caveolae. J Cell Biol 141:85-99

41. Oh P, Mclntosh DP, Schnitzer JE (1998) Dynamin at the neck of caveolae mediates their budding to form transport vesicles by GTP-driven fission from the plasma membrane of endothelium. J Cell Biol 141:101-114

42. Hill TA, Mariana A, Gordon CP, Odell LR, Robertson MJ, McGeachie AB, Chau N, Daniel JA, Gorgani NN, Robinson PJ, McCluskey A (2010) Iminochromene inhibitors of dynamins I and II GTPase activity and endocytosis. J Med Chem 53:4094-4102

43. Preta G, Cronin JG, Sheldon IM (2015) Dynasore—not just a dynamin inhibitor. Cell Commun Signal 13:24

44. Quan A, McGeachie AB, Keating DJ, van Dam EM, Rusak J, Chau N, Malladi CS, Chen C, McCluskey A, Cousin MA, Robinson PJ (2007) Myristyl trimethyl ammonium bromide and octadecyl trimethyl ammonium bromide are surface-active small molecule dynamin inhibitors that block endocytosis mediated by dynamin I or dynamin II. Mol Pharmacol 72:1425-1439

45. Xu Q, Cao M, Song H, Chen S, Qian X, Zhao P, Ren H, Tang H, Wang Y, Wei Y, Zhu Y, Qi Z (2016) Caveolin-1-mediated Japanese encephalitis virus entry requires a two-step regulation of actin reorganization. Future Microbiol 11:1227-1248

46. Dietzel E, Kolesnikova L, Maisner A (2013) Actin filaments disruption and stabilization affect measles virus maturation by different mechanisms. Virol J 10:249

47. Samson F, Donoso JA, Heller-Bettinger I, Watson D, Himes RH (1979) Nocodazole action on tubulin assembly, axonal ultrastructure and fast axoplasmic transport. J Pharmacol Exp Ther 208:411-417

48. Hernaez B, Alonso C (2010) Dynamin- and clathrin-dependent endocytosis in African swine fever virus entry. J Virol 84:2100-2109

49. Vincent MJ, Bergeron E, Benjannet S, Erickson BR, Rollin PE, KsiazekTG, Seidah NG, Nichol ST (2005) Chloroquine is a potent inhibitor of SARS coronavirus infection and spread. Virol J 2:69

50. Dille BJ, Johnson TC (1982) Inhibition of vesicular stomatitis virus glycoprotein expression by chloroquine. J Gen Virol 62:91-103

51. Wudiri GA, Nicola AV (2017) Cellular cholesterol facilitates the postentry replication cycle of herpes simplex virus 1. J Virol 91:e00445-e00517

52. Jancekova B, Ondrouskova E, Knopfova L, Smarda J, Benes P (2016) Enzymatically active cathepsin D sensitizes breast carcinoma cells to TRAlL. Tumour Biol 37:10685-10696

53. Achour O, Bridiau N, Kacem M, Delatouche R, Bordenave-Juchereau S, Sannier F, Thiery V, Piot JM, Maugard T, Arnaudin I (2013) Cathepsin D activity and selectivity in the acidic conditions of a tumor microenvironment: utilization in the development of a novel Cathepsin D substrate for simultaneous cancer diagnosis and therapy. Biochimie 95:2010-2017

54. Geisow MJ, Evans WH (1984) pH in the endosome. Measurements during pinocytosis and receptor-mediated endocytosis. Exp Cell Res 150:36-46

55. Wang JL, Zhang JL, Chen W, Xu XF, Gao N, Fan DY, An J (2010) Roles of small GTPase Rac1 in the regulation of actin cytoskeleton during dengue virus infection. PLoS Negl Trop Dis 4:e809

56. Lin H, Li B, Chen L, Ma Z, He K, Fan H (2017) Differential protein analysis of IPEC-J2 cells infected with porcine epidemic diarrhea virus pandemic and classical strains elucidates the pathogenesis of infection. J Proteome Res $16: 2113-2120$

57. Li J, Jin Z, Gao Y, Zhou L, Ge X, Guo X, Han J, Yang H (2017) Development of the full-length cDNA clones of two porcine epidemic diarrhea disease virus isolates with different virulence. PLoS One 12:e0173998

58. Hemida MG, Alnaeem A, Chu DK, Perera RA, Chan SM, Almathen F, Yau E, Ng BC, Webby RJ, Poon LL, Peiris M (2017) Longitudinal study of Middle East Respiratory Syndrome coronavirus infection in dromedary camel herds in Saudi Arabia, 2014-2015. Emerg Microbes Infect 6:e56

59. Blau DM, Holmes KV (2001) Human coronavirus HCoV-229E enters susceptible cells via the endocytic pathway. Adv Exp Med Biol 494:193-198

60. Milewska A, Nowak P, Owczarek K, Szczepanski A, Zarebski M, Hoang A, Berniak K, Wojarski J, Zeglen S, Baster Z, Rajfur Z, Pyrc K (2017) Entry of human coronavirus NL63 to the cell. JVirol 92:e01933-e02017

61. Ren X, Glende J, Yin J, Schwegmann-Wessels C, Herrler G (2008) Importance of cholesterol for infection of cells by transmissible gastroenteritis virus. Virus Res 137:220-224 
62. Pratelli A, Colao V (2015) Role of the lipid rafts in the life cycle of canine coronavirus. J Gen Virol 96:331-337

63. Kooi C, Cervin M, Anderson R (1991) Differentiation of acid-pH-dependent and -nondependent entry pathways for mouse hepatitis virus. Virology 180:108-119

64. Eifart P, Ludwig K, Bottcher C, de Haan CA, Rottier PJ, Korte T, Herrmann A (2007) Role of endocytosis and low pH in murine hepatitis virus strain A59 cell entry. J Virol 81:10758-10768

65. Choi KS, Aizaki H, Lai MM (2005) Murine coronavirus requires lipid rafts for virus entry and cell-cell fusion but not for virus release. J Virol 79:9862-9871

66. Qinfen Z, Jinming C, Xiaojun H, Huanying Z, Jicheng H, Ling F, Kunpeng $L$, Jingqiang Z (2004) The life cycle of SARS coronavirus in Vero E6 cells. $J$ Med Virol 73:332-337
67. Matsuyama S, Nagata N, Shirato K, Kawase M, Takeda M, Taguchi F (2010) Efficient activation of the severe acute respiratory syndrome coronavirus spike protein by the transmembrane protease TMPRSS2. J Virol 84:12658-12664

68. Owczarek K, Szczepanski A, Milewska A, Baster Z, Rajfur Z, Sarna M, Pyrc K (2018) Early events during human coronavirus OC43 entry to the cell. Sci Rep 8:7124

69. Chu VC, McElroy LJ, Chu V, Bauman BE, Whittaker GR (2006) The avian coronavirus infectious bronchitis virus undergoes direct low-pH-dependent fusion activation during entry into host cells. J Virol 80:3180-3188

70. Imhoff H, von Messling V, Herrler G, Haas L (2007) Canine distemper virus infection requires cholesterol in the viral envelope. J Virol 81:4158-4165
Ready to submit your research? Choose BMC and benefit from:

- fast, convenient online submission

- thorough peer review by experienced researchers in your field

- rapid publication on acceptance

- support for research data, including large and complex data types

- gold Open Access which fosters wider collaboration and increased citations

- maximum visibility for your research: over $100 \mathrm{M}$ website views per year

At BMC, research is always in progress.

Learn more biomedcentral.com/submissions 